\title{
Problematic consumption of drugs and risk or protection factors in a reclusion center of the city of Mexico
}

\section{Consumo problemático de drogas y factores de riesgo o protección en un centro de reclusión de la Ciudad de México}

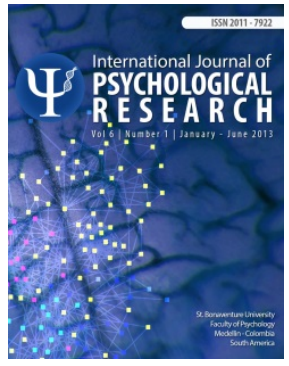

Octavio Enrique Aguilar Bustos ${ }^{\text {E, a, }}$, Gayle Rosio Valdez Gonzales, Miguel Ángel López Brambila $^{\mathrm{c}}$, Andrea Gallegos Cari ${ }^{\mathrm{d}}$, Rafael Camacho Solís ${ }^{\mathrm{e}}$, Miguel Angel Mendoza Meléndez ${ }^{\mathrm{f}}$

a Jefe de unidad departamental de investigación cualitativa. Instituto para la Atención y Prevención de las Adicciones, México Distrito Federal.

${ }^{b}$ Subdirectora de investigación epidemiológica y dinámica de consumo. Instituto para la Atención y Prevención de las Adicciones, México Distrito Federal.

${ }^{c}$ Jefe de unidad de departamental de investigación cuantitativa. Instituto para la Atención y Prevención de las Adicciones, México Distrito Federal.

${ }^{d}$ Asistente de investigación. Instituto para la Atención y Prevención de las Adicciones, México Distrito Federal.

e Director General del Instituto para la Atención y Prevención de las Adicciones, México Distrito Federal.

${ }^{f}$ Director ejecutivo de investigación y evaluación. Instituto para la Atención y Prevención de las Adicciones, México Distrito Federal.

\section{ABSTRACT}

The aim of this study was to explore the relation between the problematic consumption of drugs and some variables: age, time of imprisonment, education, legal situation, committing a crime under drugs effect and number of visits received. Data of inmates who had accepted they were consuming drugs at the moment of doing the study was analyzed. It was found that the problematic consumers were younger and had less time of imprisonment. The inmates with less education, the ones who were being processed at the moment of doing the study, the ones who had committed crimes under the drugs effect and the ones who did not receive any visit showed more problems (measured through the DAST questionnaire) associated to the consumption. Some hypotheses about the results are discussed.

\section{RESUMEN}

El objetivo del estudio fue explorar la relación entre el consumo problemático de drogas y las variables: edad, tiempo de reclusión, escolaridad, situación jurídica, haber cometido un delito bajo efecto de drogas y haber recibido visitas en prisión. Se analizaron datos de internos que aceptaron que consumían drogas al momento del estudio. Se encontró que los consumidores problemáticos tenían menor edad y menos tiempo de reclusión. Los internos con menor escolaridad, los que estaban siendo procesados al momento del estudio, los que cometieron el delito bajo efecto de drogas y los que no recibían visitas mostraron más problemas (medidos a través del cuestionario DAST) asociados a consumo. Se discuten hipótesis sobre los resultados.

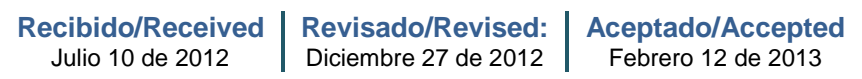

Enrique Aguilar Bustos, Av. Río Mixcoac 234. Colonia Acacias. Delegation Delegación Benito Juárez. C.P. 03240. México Distrito Federal, E-Mail: enrikeaguilarb@gmail.com 


\section{INTRODUCTION}

The problematic consumption of drugs is not necessary related to the frequency or the quantity consumed but to the disturbances generated in the individual life. They could be related to financial, health, psychological, family, social and legal alterations as can be measured in the questionnaire of Drug Abuse Screening Test, DAST (De las Fuentes y Villalpando, 2001).

Most of the crimes are committed under the effect of psychoactive substances (United Nations Office on Drug and Crime, n. d.) and a high rate of the number of people are imprisoned in the penitentiaries because of minor crimes (Bergman, 2007). According to the information collected in June 21th 2012, the population in the penitentiaries of Mexico city was more than 42 thousand inmates, which represents an increase of more than 10 thousand since 2006 (Subsecretaría de Sistema Penitenciario, 2012). 25\% of the imprisonments in the Consejo Tutelar de Menores in 2009 were caused by crimes committed under the influence of any drug, principally inhalant ones and alcohol, being the most usual theft and carrying of weapons (Sistema de Vigilancia Epidemiológica, 2010). on the other hand, the consumption of substances is a constant phenomenon in the prisons (Dolan, Khoei, Bretari \& Stevens, 2008).

Some factors related to damaging consumption of drugs are recognized in general population such as environmental factors (Arthur, Hawkins, Pollard, Catalano \& Baglioni, 2002), certain personality features (Sánchez de León et al., 2009), the genetic predisposition (Wong \& Schuman, 2008) and certain brain functioning deficiencies (Aytaclar, Tarter, Kirisci \& Lu, 1999). However, it has been studied vaguely about some factors that can be related to the consumption way of people in the penitentiaries. It has been publish large studies in relation to the consumption in penitentiaries. Nevertheless, its main purpose has been finding the prevalence of use, abuse and dependence of the different substances (Dolan, et al., 2008; Fazel, Bains \& Doll, 2006).

Some variables such as age (Comisión Interamericana para el Control y el Abuso de Drogas,
2012), education (Baker, León, Smith, Collins \& Movit, 2011) and family support (Which can be consider as family visits) (Medina and Carvalho, 2010) have been related to the consumption of substances in general population. For this reason, they have been considered for this study. Additionally, it was proposed to explore if other typical variables in the penitentiaries, such as time of imprisonment, committing a crime under drugs effect and inmate legal status could keep a relation with the said consumption.

The treatment in the penitentiaries against addictions represents benefits as much as for the inmate as for the society because it helps the inmate to overcome his addiction problems and at the same time, it has an impact regarding the relapse (Mcmuran, 2007; Pelisser et al., 2001). Thus, it is necessary to understand better the variables associated to the drugs consumption in penitentiaries for developing more efficient programs. This study was purposed to explore the relationship between some of the typical variables of the penitentiary environment and the inmates' problematic consumption

\section{METHOD}

\subsection{Participants}

Table 1. Distribution of interviewee according to their education level

\begin{tabular}{l|r|r}
\hline & $\mathbf{N}$ & Percentage \\
\hline Illiterate & 73 & 2.9 \\
Unfinished primary & 262 & 10.3 \\
Finished primary & 661 & 25.9 \\
Unfinished secondary & 414 & 16.2 \\
Finished secondary & 786 & 30.8 \\
Unfinished high school & 173 & 6.8 \\
Finished high school & 117 & 4.6 \\
Technical degree & 18 & .7 \\
Unfinished degree & 25 & 1.0 \\
Finished degree & 19 & .7 \\
Postgraduate studies & 2 & .1 \\
Other & 2 & .1 \\
\hline Total & $\mathbf{2 5 5 2}$ & $\mathbf{1 0 0 . 0}$ \\
\hline
\end{tabular}

The 8077 inmates of Reclusorio Varonil Sur of Mexico were interviewed. During the period of its implementation, 5552 cases of inmates who admitted they consumed at least one kind of drugs were 
analyzed. The age range among these individuals was between 17 and 18 years old $(=32.09$; $D E=8.384$ ), with education from illiterate to postgraduates according to the next distribution:

\subsection{Instrument}

It was designed an instrument that included the items of the DAST in its 20 items version which was adapted to the Mexican population (De las Fuentes y Villalpando, 2001), as well as questions related to the age, education, time of imprisonment , legal situation, committing a crime under the effect of drugs, number of visits received and current drugs consumption.

The DAST is an instrument that measures problematic consumption of drugs. It was originally designed by Skinner (1982) and it consists of 28 dichotomic questions (YES/NO). There are versions of 20 and 10 items of this instrument, also developed by their original author. The questions of this instrument measure features related to the exorbitant drugs consumption and to the physical, psychological and social complications which are the cause of that consuming.

\subsection{Variables}

\section{Dependent variable}

Problems associated to drugs consumption, measured through the score obtained by the inmates in the DAST.

\section{Independent variables}

The variables are: Age, which was measured in the age reported by the inmate; time of imprisonment, considered as the number of days since the penitentiary entry date to the interview date; education, considered as the next categories according to the reported by the inmates: illiterate, unfinished primary, finished primary, unfinished high school, finished high school, preparatory or similar education unfinished, preparatory or similar education finished, technical degree, unfinished degree, finished degree, postgraduate study and others; legal situation, considering the processed, convicted and definitive status; committing crimes under the effect of any substance; receiving visits, which is consider an indicator of family support.

\section{RESULTS}

Marijuana and alcohol were the most consumed drugs. This consumption was distributed as the following chart shows (Table 2):

Table 2. Distribution of population regarding the drug they consume*

\begin{tabular}{lrr}
\hline Substance & $\mathbf{N}$ & $\mathbf{\%}$ \\
\hline Alcohol & 464 & $18.2 \%$ \\
Inhalable drugs & 262 & $10.3 \%$ \\
Marihuana & 1530 & $60.0 \%$ \\
Cocaine & 509 & $19.9 \%$ \\
Sedatives & 6 & $.2 \%$ \\
Amphetamines and methaphetamines & 30 & $1.2 \%$ \\
Opioid & 7 & $.3 \%$ \\
Others & 514 & $20.1 \%$ \\
\hline
\end{tabular}

${ }^{*}$ The amount of the percentage is higher to 100 because some inmates consume more than one drug.

$50.7 \%$ of the population studied has committed the crime under the effect or any drug. Regarding their legal status, $12.9 \%$ were being processed, $61.9 \%$ were sentenced and $23.8 \%$ were in definitive status. The $1.4 \%$ remaining did not know or did not answer. In addition, $13.8 \%$ received visits and $84 \%$ did not. The rest of inmates did not answer.

According to the percentage obtained in the DAST, the individuals were classified as problematic and non-problematic consumers using 6 as the cutoff point. Meaningful differences, as far as the age is concerned, were found between problematic and non-problematic consumers $(t=0.608 ; p<0.001)$, where he youngest inmates were in the problematic group. The average age of the problematic group was $=31.99(\mathrm{DE}=7.466)$ versus $=32.19(\mathrm{DE}=9.118)$ of the non-problematic one. They were found some differences regarding the time they have been in jail as well $(t=3.186 ; p<0.001)$, where the problematic group has been less time in prison. They presented an average of 1198 days ( $D E=1080.094$ ) while the non-problematic group presented an average of 1348.69 (DE=1303.77).

The inmates were divided in two groups: one with low education that included those who reported being illiterate and those who just studied primary or 
secondary school, and another one with high education including those who studied high school, technical career and bachelor or postgraduate studies. The inmates who reported "Other" education were excluded. Comparing these two groups, they were found meaningful differences in their results in the DAST ( $t=-4.461 ; p<0.001)$. Generally, it was observed that the less they had education, the higher scores they got in the DAST (Figure 1).

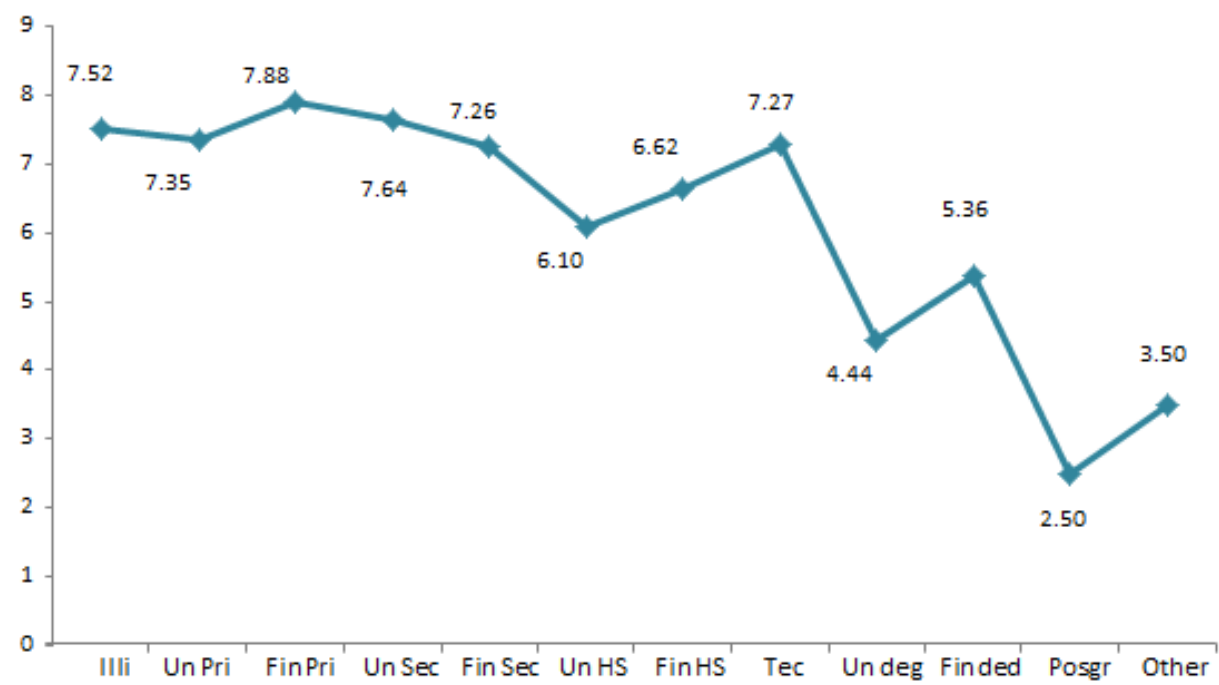

Figure 1. Average DAST score according to the inmates' education. Generally, it is observed that the low education levels show more problems associated to consumption. Illi = Illiterate, Un Pri. = Unfinished primary, Fin Pri = Finished primary, Un Sec = Unfinished secondary, Fin Sec = Finished secondary, Un HS = Unfinished high school, Fin HS = Finished high school, Tec = technical career, Un deg = Unfinished degree, Fin ded = Finished degree and Posgr $=$ Postgraduate studies

Regarding the legal status, they were found meaningful differences between the three status $(F=6.062 ; p=0.002)$, being the processed group the one that had the highest score in the DAST in relation to the convicted group $(-1.094)$ and the definitive one (-0.858). Concerning the comparison in terms of having committed the crime or not under the influence of drugs, differences were also significant $(t=17.91 ; p<0.001)$. The highest scores in the DAST were obtained in the group that has committed the crime under the effect of any drug ( $\overline{\mathrm{X}}=9.09$; $\mathrm{DE}=5.062)$ versus those who has not committed the crime under drugs effects $(\overline{\mathrm{X}}=5.65 ; \mathrm{DE}=4.752)$. They were also compared the DAST scores of the inmates who received visits against those who did not and they were found meaningful differences ( $t=4.027$; $p<0.001)$. The highest score was observed in the group that did not receive visits $(\overline{\mathrm{X}}=8.36 ; \mathrm{DE}=5.01)$ in relation to those who did ( $\bar{x}=7.19 ; \mathrm{DE}=5.218)$.

\section{DISCUSSION}

According to the results, it is observable that young consumers of psychoactive substances have more probabilities of being problematic consumers. In general, in the higher rates of drug consumption are mainly people between the 18 and 34 years (Comisión Interamericana para el Control y el Abuso de Drogas, 2012), That consumption is related to characteristics such as impulsiveness and lack of self-control (Winstanley, Olausson, Taylor \& Jentsch, 2010). In fact, that impulsivity and related features are associated with age and so on. Searching of new feelings and impulsiveness, have a special increase during puberty and a decrease during aging (Steinberg, et al., 2008). It was observed that schooling levels are related to negative features as mortality, smoking, drug abusing and accidents (Baker et al., 2011), which agrees with the results of this study. This association can be explained, in a certain way, based on the Function of the Self, which is an aspect related to drug 
abuse (Fine \& Juni, 2000). A nonfunctional Self prompt the development of addiction behaviors, and schooling has a positive relation to the good functioning of the Self (Juni \& Stack, 2005). However, it is necessary to determine if a functional Self prompts the good academic efficiency and avoid addictions or if it is the formal education that reinforce the Self and protect against addictions. Another interpretation of this result deals with the access to information about the consequences of drug consumption; in this way, the people with more information can tackle better problems associated with consumption. It could be considered also the fact that many people with low education grow up generally in environments with not many opportunities, which prompts the damaging consumption of drugs (Buchanan, 2006). In that way, the academic training could protect against the development of problems associated with drug consumption.

The legal situation is also related to drug consumption problems, the individuals who were in process presented more problems related to drug consumption. In general, this difference could be associated to the emotional symptomatology that is acquired by being sent to prison. This result coincides with a linear decreasing model of relation between the mood and the prison permanence. According to Ruiz (2007), the recent inmates had the higher rates of emotional symptomatology, but as time go in prison it decreases. This interpretation also deals with the results obtained from the comparison about time of imprisonment since inmates with more time in prison had more problems with drug consumption.

It is not surprising that the relation between committing a crime under the influence of alcohol and the score obtained in the DAST. It has been reported that the family communication and affection can protect against psychoactive substances abuse (Medina and Carvalho, 2010). In this study, the inmates that received visits had less problems associated to drug consumption than those who did not.

\section{CONCLUSION}

As we can see, there is a different factor implicated in the psychoactive substances consumption phenomenon which should be studied and considered for its right confrontation. This work represents a first attempt to explore the variables that can be associated to the psychoactive substances consumption inside of the penitentiaries. It is necessary to take into account the context and the characteristics of each individual at the moment of planning and developing procedure strategies inside of these centers. According to our results, at least some features such as the time that the individual has remained in detention, age, education, legal status, visits and crimes committed under the influence of drugs. It is also necessary to perform new measurements within each specific context and consider them as part of each planning program.

\section{LIMITATIONS AND FUTURE RESEARCH}

In general, this is a first attempt that allowed us to explore some of the variables in the prison environment and its relation to the problematic consumption of drugs. This study considered the entire prison population which prevented measurements of other variables that might be relevant to the matter. For instance, consumption patterns, dependency and its levels or other risk factors or protection. That is why it is recommended choosing just one representative sample in order to obtain a greater volume of variables in related future researches.

\section{REFERENCES}

Arthur, M. W., Hawkins, J. D., Pollard, J. A., Catalano, R. F. \& Baglioni, A. J. (2002). Measuring Risk and Protective Factors for Use, Delinquency, and Other Adolescent Problem Behaviors. The Communities That Care Youth Survey. Evaluation Review, 26, 575-601.

Aytaclar, S., Tarter, R. E., Kirisci, L.\& Lu, S. (1999). Association between hyperactivity and executive cognitive functioning in childhood and substance use in early adolescence. Journal of the American Academy of Child and Adolescent Psychiatry, 38(2),172-178.

Baker, D., Leon, J., Smith, E., Collins, J. \& Movit, M. (2011).The Underappreciated Education Effect on Population Health: A Theoretical 
Reassessment, Meta-analysis of Education and Mortality, and a Cognitive Hypothesis. Population and Development Review, 37(2), 307-332.

Bergman, M. y Azaola, E. (2007). Cárceles en México: Cuadros de una crisis. Urvio: Revista Latinoamericana de Seguridad Ciudadana, 1, 74-87.

Buchanan, J. (2006). Understanding Problematic Drug Use: A Medical Matter or a Social Issue. British Journal of Community Justice, 4(2), 387-397.

Comisión Interamericana para el Control y el Abuso de Drogas (2012). Informe del Uso de Drogas en las Américas 2011. Recuperado de http://www.cicad.oas.org/oid/pubs/Uso_de_ Drogas_en_Americas2011_Esp.pdf

De las Fuentes V. M. y Villalpando, J. (2001). Adaptación de un instrumento de tamizaje para la población mexicana que consume drogas. Tesis de Licenciatura. Facultad de Psicología. Universidad Nacional Autónoma de México. Recuperado de http://132.248.9.195/pd2001/294058/Index. html

Dolan, K., Khoei, E. M., Bretari, C. \& Stevens, A. (2008). Prison and Drugs: A global review of incarceration, drugs use and drug treatment. Recuperado de Beckley Foundation Drug Policy Program.

Fazel, S., Bains, P. \& Doll, H. (2006). Substance abuse and dependence in prisoners: A systematic review. Addiction, 101, 181-191.

Fine, J. \& Juni, S. (2000). Ego Atrophy in Addiction Illustrated through American Cultural Music Folklore. Current Psychology: Developmental, Learning, Personality, Social, 19(4), 312-328.

Juni, S. \& Stack, J. E. (2005). Ego Function as a Correlate of Addiction. The American Journal on Addictions, 14, 83-93.

Mcmuran, M. (2007). What works in substance misuse treatments for offenders? Criminal Behaviour and Mental Health, 17, 225-233.

Medina, N. y Carvalho, M. G. (2010). Factores protectores de las familias para prevenir el consumo de drogas en un municipio de Colombia. Revista Latino-Americana de Enfermagem, 18(Spec.), 504-512.

Pelisser, B., Walace, S., O'Neall, J. A., Gaes, G.G., Camp, S., Rhodes, W. \& Saylor W. (2001). Federal Prison Residential Drug Treatment Reduces Substance Use And Arrests After
Release. American Journal of Drug and Alcohol Abuse, 27(2), 315-337.

Ruiz, J. I. (2007). Síntomas psicológicos, clima emocional, cultura y factores personales en el medio penitenciario. Revista Latinoamericana de Psicología, 39, 547561.

Sánchez de León, J. M., Pedrero, E. J., Olivar, A., Llanero, M., Rojo, G. y Puerta, C. (2009). Personalidad y sintomatología frontal en adictos y población no clínica: hacia una neuropsicología de la personalidad. Adicciones, 22, 233-244.

Sistema de Vigilancia Epidemiológica. (2010). Informe2009. Recuperado de http://www.dgepi.salud.gob.mx/2010/PDFS/ SISVEA/informes_sisvea_2009.pdf

Skinner, H. (1982). The Drug Abuse Screening Test. Addictive Behaviors, 7, 363-371.

Steinberg, L., Albert, D., Cauffman, E., Banich, M., Graham, S. \& Woolard, J. (2008). Age differences in sensation seeking and impulsivity as indexed by behavior and selfreport: evidence for a dual systems model. Developmental Psychoogyl, 44, 1764-1778.

Subsecretaría de Sistema Penitenciario (2012). Movimiento diario de población penitenciaria. Recuperado de http://www.sistemapenitenciario.df.gob.mx/r eclusorios/estadisticas/index.html

United Nations Office on Drug and Crime (n.d.).Drug Dependence Treatment: Interventions for drug users in prison. Retrieved from http://www.unodc.org/docs/treatment/111_P RISON.pdf

Winstanley, C. A., Olausson, J. R. \& Taylor, J. D. (2010). Insight Into the Relationship Between Impulsivity and Substance Abuse From Studies Using Animal Models. Alcoholism: Clinical and Experimental Research, 34, 1-13.

Wong, C. \& Schuman, G. (2008). Genetics of addictions: strategies for addressing heterogeneity and polygenicity of substance use disorders. Philosophical Transactions of the Royal Society B, 353, 3213-3222. 